Tropical Agricultural Pesearch \& Extension 21 (1 \& 2): 2018

\title{
OPTIMIZATION OF WHEAT-SORGHUM COMPOSITE FLOUR FOR THE PRODUC- TION AND ENHANCED STORABILITY OF LEAVENED FLAT BREAD NAAN
}

T Mahendran ${ }^{1 *}$ and G Hariharan ${ }^{2}$

${ }^{1}$ Department of Agricultural Chemistry, Faculty of Agriculture, Eastern University, Sri Lanka

${ }^{2}$ Department of Biosystems Technology, Faculty of Technology, Eastern University, Sri Lanka.

\begin{abstract}
The use of wheat composite flour for commercial production and consumption of leavened flat bread Naan are not yet popularized in Sri Lanka. The present study assessed the effect of optimization of composite flour on the quality of Naan by mixing wheat and sorghum flour at different ratios. Sorghum flours were used 0, 10, 20, 30, 40 and $50 \%$ by weight to replace the wheat flour in the Naan. The formulated Naan were assessed for physicochemical and organoleptic qualities. The moisture, protein, fiber, minerals, loaf weight and loaf volume of the developed Naan were evaluated. The highest moisture content $(11.13 \%)$ was recorded in the Naan made with $100 \%$ wheat flour whereas $50 \%$ incorporation resulted in decreased moisture content of $8.11 \%$. The fiber content increased from 4.78 to $6.04 \%$ with the increment of sorghum flour substitution from 0 to $50 \%$. The highest mineral content of $2.91 \%$ was recorded from $50 \%$ sorghum flour contained Naan. The highest Naan bread volume of $233 \mathrm{~cm}^{3}$ obtained from $100 \%$ wheat flour, while the mixture containing $50 \%$ sorghum flour resulted in the lower volume of $187 \mathrm{~cm}^{3}$. As revealed by the sensory evaluation, Naan supplemented with $40 \%$ sorghum flour was well acceptable in terms of colour, taste, texture, aroma and overall acceptability. The mixture of $40 \%$ sorghum flour and $60 \%$ wheat flour was found to be successful for the production of leavened bread Naan with improved physico-chemical and organoleptic qualities within the universally accepted standards. Based on the storage studies, the Naan packed in the low density polyethylene could be frozen stored at $-10^{\circ} \mathrm{C}$ for 90 days without any significant changes in the quality characteristics.
\end{abstract}

Key words: Composite flour, Naan, Nutritional quality, Sorghum, Wheat

\section{INTRODUCTION}

Wheat (Triticum aestivum), a staple food of large proportion of the world population, has been the major ingredient of leavened bread for many years due to its functional gluten proteins. In Sri Lanka, the consumption of bread or "take away" products are increasing in both rural and urban areas as a consequence of changing lifestyle, convenience and high cost of cooking energy (Ekanayake et al., 2016). Wheat is also extensively used for the production of flat breads such as the naan, parotta and steam-leavened chapatti in India, Sri Lanka, China, Middle East and some parts of
Africa (Parimala and Sudha, 2015). However, bread can be made from high gluten wheat which is difficult to grow in the tropical areas due to the prevailing climatic conditions (Carson and Sun, 2000). Developing countries have encouraged assessing the feasibility of alternative locally available flours as a substitute for wheat flour. Many researches (Olaoye et al., 2006; Turner, 2007), have been carried out to promote the use of composite flours, in which a portion of wheat flour is replaced by locally grown crops, to be used in bread, thereby decreasing the cost of imported wheat.

*Corresponding author: thevamahen@yahoo.com 
The total production of sorghum (Sorghum bicolor Pers.) in Sri Lanka is $103.62 \mathrm{t}$ in 2018 maha (Department of Census and Statistics, 2018) and is more likely to be that the grains are under-utilized. Processing of sorghum grains into flour would increase its utilization and a good source of nutrients such as carbohydrates, $\beta$-carotene and vitamin $\mathrm{C}$, minerals such as calcium, phosphorus (Kent and Evers, 1994), iron, manganese (Mutegi et al., 2010) and zinc and can contribute to the dietary fiber, color and flavor in food preparations. Therefore, the use of sorghum flour for production of baked goods if feasible would help to lower the dependency of developing nations on imported wheat.

Numerous studies have shown the possibility of supplementing sorghum flour for wheat flour at various levels to produce bread when wheat is in short supply. Abdelghafor et al. (2011) investigated the rheological properties and baking potential of sorghum based composite flour containing variable amount of wheat gluten. In line with this situation, there is a possibility of incorporating sorghum flour into local foods in Sri Lanka, replacing wheat flour or rice flour. Considering all above factors, this research was designed to incorporate the sorghum flour with the wheat flour for the development of leavened flat bread Naan.

\section{MATERIALS AND METHODS}

Sorghum (cv. Kafir) grains were obtained from the Department of Agriculture, Batticaloa, Sri Lanka. The grains were cleaned to remove the foreign materials and then pearled in a hand operated chakki for removal of husk. The pearled grains were ground in a grinder (Alikeleyisi, flat wheel grinder) to make fine powder and passed through $250 \mu \mathrm{m}$ sieves to obtain uniform size flour. All-purpose wheat flour was purchased from Prima Company (Pvt.) Ltd., Trincomalee. Sugar (sucrose, white, granulated), salt ( $\mathrm{NaCl}$, commercial grade) shortening (partially hydrogenated vegetable oil) and instant dry yeast and water at $37^{\circ} \mathrm{C}$ were also used as ingredients.

\section{Preparation of Composite Flour Blends}

Sorghum flour was blended with 0, 10, 20, 30, 40 and $50 \%$ wheat flour using a Cross-Flow blender (Patterson Kelly Co., USA) operated for 30 mins to produce homogenous $1 \mathrm{~kg}$ blends. The composite flours were stored in air tight containers in a freezer until needed.

\section{Preparation of Leavened Flat Bread Naan}

The standard formula used for leavened flat bread Naan was $300 \mathrm{~g}$ sorghum-wheat composite flour, $4.5 \mathrm{~g}$ yeast, $4.5 \mathrm{~g}$ salt, $9 \mathrm{~g}$ shortening, $9 \mathrm{~g}$ sugar and water. All dry ingredients were weighed and placed in a mixer (Cuisinart Food Mixer, Model 4430) for $5 \mathrm{sec}$. Yeast was dissolved in luke warm water and stand for 10 mins, until frothy. Add the yeast water into the dry mixture was further run at high speed for $90 \mathrm{sec}$. The dough temperature was 30.1$31.2^{\circ} \mathrm{C}$ after mixing. Dough was scaled into three portions, rounded into balls by hand and placed in lightly greased trays and placed in the fermentation cabinet (National Company, Lincoln, NE) at $30^{\circ} \mathrm{C}$ and $90 \% \mathrm{RH}$ for $20 \mathrm{~min}$.

Dough was rolled into thin sheets of $5 \mathrm{~mm}$, cut into $15 \mathrm{~cm}$ diameter, placed in lightly greased pans and returned to the fermentation cabinet for a final proof for 45 mins. When the height of dough had risen to double the volume, the pans were placed in a pre-heated convection oven (Despatch oven Company, USA) and bake at $220^{\circ} \mathrm{C}$ for about 15 minutes until the bread is puffed and just browned.

\section{Assessment of Nutritional, Physical and Sen- sory Attributes of Naan}

Nutritional qualities of moisture, protein, fiber and minerals were assessed using the standard AOAC (2000) methods and the difference between means was compared using Duncan's Multiple Range Test. The loaf volume was measured by rapeseed displacement immediately after removal from the oven and weighing (Mettler 240A). Loaves were placed in a container of known volume into which rapeseeds were placed until the container was full. The volume of seeds displaced by the loaf was con- 
sidered as the loaf volume.

Sensory parameters including colour, taste, texture, aroma and overall acceptability were evaluated using a trained 20 -member sensory panel. Ranking test was used to evaluate the perceptive differences in intensity of each attribute among samples and the results were analyzed using Tukey's test using SAS software statistical package.

\section{RESULTS AND DISCUSSION \\ Nutritional Qualities of Wheat and Sor- ghum Flours Used in this Study}

The results of nutritional analysis of wheat and sorghum flour used in the wheat-sorghum composite flour added naan is presented in Table 1.

Table 1: Nutritional analysis of Wheat Flour and Sorghum Flour

\begin{tabular}{lll}
\hline $\begin{array}{l}\text { Nutritional } \\
\text { Composition }\end{array}$ & $\begin{array}{c}\text { Wheat } \\
\text { Flour }\end{array}$ & $\begin{array}{c}\text { Sorghum } \\
\text { Flour }\end{array}$ \\
\hline Moisture (\%) & $11.13 \pm 0.08$ & $10.06 \pm 0.07$ \\
Protein (\%) & $12.33 \pm 0.05$ & $8.62 \pm 0.08$ \\
Fiber (\%) & $4.74 \pm 0.03$ & $7.13 \pm 0.04$ \\
Fat (\%) & $1.87 \pm 0.01$ & $2.01 \pm 0.02$ \\
Minerals (\%) & $2.09 \pm 0.02$ & $3.74 \pm 0.02$ \\
\hline
\end{tabular}

Values are means of three replicates \pm standard error.

\section{Nutritional Qualities of Wheat-Sorghum Composite Flour Naan}

The nutritive value of flat bread Naan depends entirely on the chemical composition of the flour and other ingredients used for its formulation. Elective constituents can be incorporated to increase processing or to produce specially and novelty breads which regularly have an improved nutritive value (Dhingra and Jood, 2001; Gocmen, et al., 2009). The effect of sorghum flour incorporation on the nutritional characteristics of flat bread Naan is presented in Table 2 .

It can be observed that the moisture content was decreased when the increase in substitution of sorghum flour in the Naan bread. The highest moisture content of $11.13 \%$ were recorded in the Naan made with $100 \%$ wheat flour $\left(\mathrm{T}_{6}\right)$ whereas $50 \%$ substitution of wheat flour by sorghum flour $\left(\mathrm{T}_{5}\right)$ reduced the moisture content of the Naan to $8.11 \%$ which is significantly $(P<0.05)$ different from other treatment combinations. This is in agreement with that reported by Abdelghafor et al., (2011), who found low moisture content associated with composite sorghum flour as opposed to $100 \%$ wheat flour. This can be attributed to lower levels of gluten protein in the dough and consequently reduce the water holding capacity of the baked product. The lower moisture content in the product would

Table 2: Nutritional Analysis of Wheat-Sorghum Composite Flour Naan

\begin{tabular}{ccccc}
\hline Treatments & $\begin{array}{c}\text { Moisture } \\
\mathbf{( \% )}\end{array}$ & $\begin{array}{c}\text { Protein } \\
\mathbf{( \% )}\end{array}$ & $\begin{array}{c}\text { Fiber } \\
(\mathbf{\%})\end{array}$ & $\begin{array}{c}\text { Minerals } \\
(\mathbf{\%})\end{array}$ \\
\hline $\mathrm{T}_{1}$ & $10.9 \pm 0.07^{\mathrm{d}}$ & $12.3 \pm 0.07^{\mathrm{d}}$ & $4.95 \pm 0.01^{\mathrm{a}}$ & $2.42 \pm 0.05^{\mathrm{a}}$ \\
$\mathrm{T}_{2}$ & $9.80 \pm 0.09^{\mathrm{c}}$ & $11.89 \pm 0.08^{\mathrm{c}}$ & $5.28 \pm 0.01^{\mathrm{ab}}$ & $2.55 \pm 0.03^{\mathrm{ab}}$ \\
$\mathrm{T}_{3}$ & $9.13 \pm 0.12^{\mathrm{b}}$ & $11.03 \pm 0.02^{\mathrm{bc}}$ & $5.57 \pm 0.00^{\mathrm{b}}$ & $2.67 \pm 0.01^{\mathrm{b}}$ \\
$\mathrm{T}_{4}$ & $8.93 \pm 0.11^{\mathrm{b}}$ & $10.78 \pm 0.07^{\mathrm{b}}$ & $5.78 \pm 0.02^{\mathrm{b}}$ & $2.73 \pm 0.02^{\mathrm{bc}}$ \\
$\mathrm{T}_{5}$ & $8.11 \pm 0.12^{\mathrm{a}}$ & $10.09 \pm 0.00^{\mathrm{a}}$ & $6.04 \pm 0.01^{\mathrm{bc}}$ & $2.91 \pm 0.01^{\mathrm{c}}$ \\
$\mathrm{T}_{6}($ Control $)$ & $11.13 \pm 0.08^{\mathrm{d}}$ & $12.47 \pm 0.12^{\mathrm{d}}$ & $4.78 \pm 0.01^{\mathrm{a}}$ & $2.38 \pm 0.03^{\mathrm{a}}$ \\
\hline
\end{tabular}

Values are means of three replicates \pm standard error.

Means with the same letters are not significantly different from each other at 5\% level based on DMRT.

$\left(\mathrm{T}_{1}-90 \mathrm{~g}\right.$ Wheat Flour $+10 \mathrm{~g}$ Sorghum Flour; $\mathrm{T}_{2}-80 \mathrm{~g}$ Wheat Flour $+20 \mathrm{~g}$ Sorghum Flour; $\mathrm{T}_{3}-70 \mathrm{~g}$ Wheat Flour $+30 \mathrm{~g}$ Sorghum Flour; $\mathrm{T}_{4}-60 \mathrm{~g}$ Wheat Flour $+40 \mathrm{~g}$ Sorghum Flour; $\mathrm{T}_{5}-50 \mathrm{~g}$ Wheat Flour $+50 \mathrm{~g}$ Sorghum Flour; $\mathrm{T}_{6}-100 \%$ Wheat Flour - Control) 
help to increase the storability of the Naan and reduce the staling effect.

The protein content significantly decreased from 12.47 to $10.09 \%$ while the fiber content increased from 4.78 to $6.04 \%$ with the increment of sorghum flour substitution from 0 to $50 \%$. This is due to low protein and high fiber content in the sorghum flour compared to wheat flour. This is supported by Akingbala et al., (2005). Highest mineral content of $2.91 \%$ was recorded for $50 \%$ sorghum flour added Naan while the minimum value of $2.38 \%$ was observed in $100 \%$ wheat flour Naan. Mineral content of composite flours increased when the level of sorghum flour supplementation was increased. This implies that the inorganic nutrients in the composite flour are richer than the wheat flour.

\section{Physical Characteristics of Wheat- Sorghum Composite Flour Naan}

Naan bread volume decreased significantly $(P<0.05)$ difference with increment of sorghum flour substitution level. The volumes of bread made from composite flours, were lower than that of made from pure wheat flour.

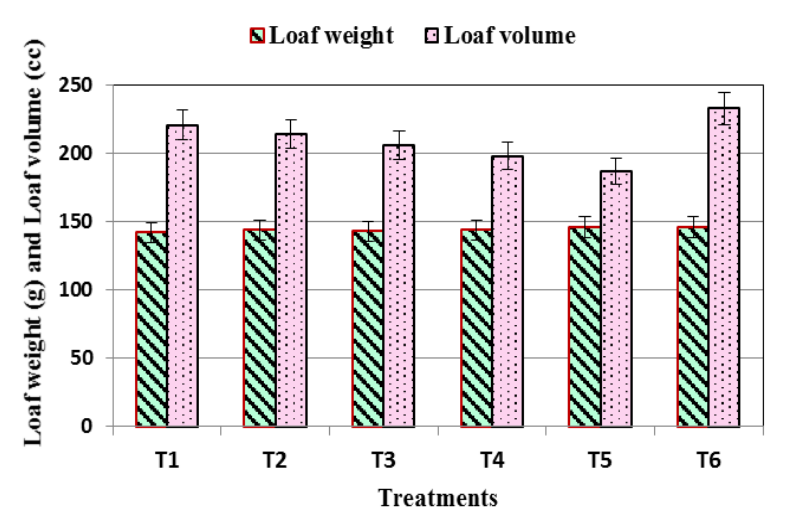

$\left(\mathrm{T}_{1}-90 \mathrm{~g}\right.$ Wheat Flour+10g Sorghum Flour; $\mathrm{T}_{2}-80 \mathrm{~g}$ Wheat Flour+20g Sorghum Flour; $\mathrm{T}_{3}-70 \mathrm{~g}$ Wheat Flour+30g Sorghum Flour; $\mathrm{T}_{4}-60 \mathrm{~g}$ Wheat Flour $+40 \mathrm{~g}$ Sorghum Flour; $\mathrm{T}_{5}$ $-50 \mathrm{~g}$ Wheat Flour $+50 \mathrm{~g}$ Sorghum Flour; $\mathrm{T}_{6}-100 \%$ Wheat

Figure 1: Effect of Sorghum Flour addition on the Loaf weight and Loaf volume of Leavened Flat Bread Naan
The highest bread volume of $233 \mathrm{~cm}^{3}$ obtained with $100 \%$ wheat flour (control), while bread containing $50 \%$ sorghum resulted in the lowest volume of $187 \mathrm{~cm}^{3}$. However, the volumes of the 10, 20, 30 and $40 \%$ levels of substitution were not significantly different from each other. This finding is in accordance with that reported by Abdelghafor et al., (2011), who found lower bread volumes associated with composite flours compared to $100 \%$ wheat flour. Similarly, Rose et al. (2013) found that, fry bread controls made from allpurpose wheat flour had larger volumes than fry bread containing sorghum and no differences in volume observed among sorghum flour containing treatments. This can be attributed to lower levels of gluten network in the dough and consequently less ability of the dough to rise, due to the low extensibility of sorghum protein. This is in agreement with the Hugo et al., (2003) who concluded that the substitution of wheat flour with upto $40 \%$ sorghum flour decreased the bread volume and Olaoye et al., (2006) who reported that the addition of sorghum to wheat flour negatively influence the loaf volume. On the other hand, Schober et al., (2007) reported that adding of sorghum flour (5-20\%) to the standard bread formula decreased the loaf volume although acceptable breads were produced.

\section{Sensory Attributes of Wheat-Sorghum Composite Flour Naan}

Sensory characteristics are the crucial criterion for the acceptance of breads and subsequently the quality built during processing must last throughout the distribution chain and until the stage of consumption (Jensen et al., 2011). Naan should be soft to touch, spongy to handfeel, somewhat firm to tear, a little chewy to bite without sticking to teeth and possess a characteristic fermented flavor and a good overall acceptability (Parimala and Sudha, 2015). Sensory scores of tested organoleptic properties of wheat-sorghum composite flour Naan are shown below in the Table 3. 
The results of the sensory qualities showed that the Naan supplemented with $40 \%$ sorghum flour were well acceptable in terms of colour, taste, texture, aroma and overall acceptability however, decline was observed in all sensory properties except aroma. These findings were in line with the observations made by many investigators (Schober et al., 2007 and Abdelghafor et al., 2011). The colour and aroma of the developed Naan were not significantly different from each other at $5 \%$ significant level in all the treatment combinations. In the case of taste, treatments were significantly differed from each other. High value was recorded for $100 \%$ wheat flour Naan while lowest was observed $50 \%$ sorghum flour supplemented Naan. For the wheat-sorghum composite flour naan bread, the sensory attributes of colour, taste, aroma and overall acceptability have deviated pattern of scores and score of texture have similar way of pattern compared with the results obtained by Akingbala et al., (2005).

Further, our findings on sensory attributes of Wheat-Sorghum flour added naan showed a comparable patterns of observations made by Dogra et al. (2001) who found that the scores for color, taste, and texture of naan decreased upon substitution of soy flour instead of wheat flour. Conversely, contradict results in sensory evaluation was observed by Wani et al. (2016) where flat bread Chapatti prepared from wheat-pulse (kidney bean and black gram) composite flours disclosed significant reduction in color, taste, aroma and overall acceptability score at $15 \%$ or higher level of replacement. The mixture of $40 \%$ sorghum flour and $60 \%$ wheat flour had been successful for the formulation of leavened flat bread Naan with acceptable nutritional and organoleptic qualities compared to the Naan made with $100 \%$ wheat flour.

\section{CONCLUSION}

Wheat flour could be substituted with sorghum flour in the manufacturing of nutritious leavened flat bread Naan. This study revealed that, up to $40 \%$ sorghum flour could be used to substitute wheat flour to produce Naan that would be acceptable by the consumers. The bread produced from wheat and sorghum composite flour had increased nutrients of carbohydrate, fiber and minerals. The use of wheat-sorghum composite flour in the production Naan would promote value addition of sorghum and diversification of utilization of the crops in Sri Lanka and in other countries in the world as well. This would create wealth and enhance food security for the world population.

Table 3: Sensory Analysis of Wheat-Sorghum Composite Flour Naan

\begin{tabular}{cccccc}
\hline Treatments & Colour & Taste & Texture & Aroma & $\begin{array}{c}\text { Overall } \\
\text { acceptability }\end{array}$ \\
\hline $\mathbf{T}_{\mathbf{1}}$ & $6.87 \pm 0.11^{\mathrm{a}}$ & $6.60 \pm 0.12^{\mathrm{a}}$ & $6.43 \pm 0.13^{\mathrm{a}}$ & $6.85 \pm 0.10^{\mathrm{a}}$ & $6.85 \pm 0.07^{\mathrm{a}}$ \\
$\mathbf{T}_{\mathbf{2}}$ & $6.64 \pm 0.05^{\mathrm{a}}$ & $6.35 \pm 0.15^{\mathrm{a}}$ & $6.31 \pm 0.11^{\mathrm{a}}$ & $6.83 \pm 0.07^{\mathrm{a}}$ & $6.70 \pm 0.09^{\mathrm{a}}$ \\
$\mathbf{T}_{\mathbf{3}}$ & $6.52 \pm 0.10^{\mathrm{a}}$ & $5.90 \pm 0.12^{\mathrm{b}}$ & $6.30 \pm 0.10^{\mathrm{ab}}$ & $6.80 \pm 0.10^{\mathrm{a}}$ & $6.55 \pm 0.10^{\mathrm{ab}}$ \\
$\mathbf{T}_{\mathbf{4}}$ & $6.47 \pm 0.05^{\mathrm{a}}$ & $5.75 \pm 0.10^{\mathrm{b}}$ & $6.21 \pm 0.11^{\mathrm{ab}}$ & $6.82 \pm 0.07^{\mathrm{a}}$ & $6.40 \pm 0.09^{\mathrm{ab}}$ \\
$\mathbf{T}_{\mathbf{5}}$ & $6.22 \pm 0.11^{\mathrm{a}}$ & $5.01 \pm 0.15^{\mathrm{c}}$ & $5.81 \pm 0.07^{\mathrm{b}}$ & $6.70 \pm 0.08^{\mathrm{a}}$ & $5.90 \pm 0.11^{\mathrm{b}}$ \\
$\mathbf{T}_{\mathbf{6}}$ & $6.89 \pm 0.05^{\mathrm{a}}$ & $6.91 \pm 0.15^{\mathrm{a}}$ & $6.50 \pm 0.11^{\mathrm{a}}$ & $6.84 \pm 0.07^{\mathrm{a}}$ & $6.90 \pm 0.10^{\mathrm{a}}$ \\
\hline
\end{tabular}

The values are means of 20 replicates \pm standard error.

The means with the same letters are not significantly different from each other at 5\% level based on Tukey's Studentized Range Test.

$\left(\mathrm{T}_{1}-90 \mathrm{~g}\right.$ Wheat Flour $+10 \mathrm{~g}$ Sorghum Flour; $\mathrm{T}_{2}-80 \mathrm{~g}$ Wheat Flour $+20 \mathrm{~g}$ Sorghum Flour; $\mathrm{T}_{3}-70 \mathrm{~g}$ Wheat Flour $+30 \mathrm{~g}$ Sorghum Flour; $\mathrm{T}_{4}-60 \mathrm{~g}$ Wheat Flour $+40 \mathrm{~g}$ Sorghum Flour; $\mathrm{T}_{5}-50 \mathrm{~g}$ Wheat Flour $+50 \mathrm{~g}$ Sorghum Flour; $\mathrm{T}_{6}-100 \%$ Wheat Flour - Control) 


\section{REFERENCES}

Abdelghafor RF, Mustafa AL, Ibrahim AMH and Krishnan PG 2011 Quality of Bread from Composite Flour of Sorghum and Hard White Winter Wheat. Advanced Journal of Food Science and Technology. 3(1): 9-15.

Akingbala JO, Oyewole OB, Uzo-Peters PI, Karim RO and Bacuss-Taylor GH 2005 Evaluating the quality of fermented sorghum flour in bakery technology. Journal of Food Agriculture and Environment. 3: 75-80.

AOAC 2000 Official Methods of Analysis, $\left(17^{\text {th }}\right.$ Edn), Association of Official Analytical Chemists, Washington D.C., New York, USA.

Arendt EK and Zannini E 2013 Cereal grains for the food and beverage industries: Woodhead Publishing Series in Food Science, Technology and Nutrition, Elsevier Science. pp 283-311.

Carson LC and Sun XS 2000 Breads from white grain sorghum: Rheological properties and baking volume with exogenous gluten protein. Applied Engineering in Agriculture. 16: 423-429.

Department of Census and Statistics, (2018). Agriculture and Environment Statistics Division, Department of Census and Statistics, Sri Lanka. Available at http://www.statistics.gov.lk/ agriculture/seasonalcrops/ SeasonalCropsNationalTotals.html, Accessed on February, 2019.

Dhingra S and Jood S 2001 Organoleptic and Nutritional Evaluation of Wheat Breads Supplemented with Soybean and Barley Flour. Food Chemistry. 77: 479-488.

Dogra J, Dhaliwal YS and Manoranjan K 2001 Effect of soaking, germination, heating and roasting on the chemical composition and nutritional quality of soybean and its utilization in various Indian leavened products. Journal of Food Science and Technology. 38: 453-457.
Ekanayake CET, Dissanayake SP and Wickramasinghe YM 2016 Trend in wheat consumption and forecast of future wheat flour consumption in Sri Lanka. Rajarata University Sri Lanka. 2 (1):118-130.

Giami SY, Amasisi TC and Ekiyor GP 2004 Comparison of bread making properties of composite flour from kernels of roasted and boiled African breadfruit. Journal of Raw Material and Research. 12: 64-70.

Gocmen D, Inkaya AN and Aydin E 2009 Flat Breads. Bulgarian Journal of Agricultural Science. 15: 298-306.

Hegedüs M, Pedersen B and Eggum BO 1985 The influence of milling on the nutritive value of flour from cereal grains. 7. Vitamins and tryptophan. Qualitas Plantarum. 35 (2): 175- 180.

Hugo LF, Rooney LW and Taylor JRN 2003 Fermented sorghum flour as a functional ingredient in composite breads. Cereal Chemistry. 80: 495-499.

Jensen S, Oestdal H, Skibsted LH, Larsen E and Thybo AK 2011 Chemical changes in wheat pan bread during storage and how it affects the sensory perception of aroma, flavor and taste. Journal of Cereal Science. 53: 259-268.

Kent NL and Evers AD 1994 Cereal crops: economics, statistics and uses. In: Kent NL and Evers AD (eds) Kent's Technology of Cereals: an Introduction for Students of Food Science and Agriculture. Oxford: Pergamon.

Mutegi E, Sagnard F, Muraya M, Kanyenji B, Rono B, Mwongera M, Marangu C, Kamau J, Parzies K, Villiers, S de, Semagn $K$, Traore PS and Labuschagne MT 2010 Eco-geographical distribution of wild, weedy and cultivated Sorghum bicolor (L.) Moench in Kenya: implications for conservation and crop -to-wild gene flow. Genetic Resources and Crop Evolution. 57 (2): 243-253.

Olaoye OA, Onilude AA and Idowu OA 2006 Quality characteristics of bread pro- 
duced from composite flours of wheat, plantain and soybeans. African Journal of Biotechnology. 5: 1102-1106.

Parimala KR and Sudha ML 2015 Wheatbased traditional flat breads of India. Critical Reviews in Food Science and Nutrition. 55 (1): 67-81.

Rose DJ, Williams E, Mkandawire NL, Weller CL and Jackson DS 2013 Use of whole grain and refined flour from tannin and non-tannin sorghum (Sorghum bicolor (L.) Moench) varieties in fry bread. Food Science and Technology International. 20(50): 333 